\title{
Public Capital and Economic Performance: Evidence from Italy*
}

\author{
Federico Bonaglia \\ OECD
}

\author{
Eliana La Ferrara \\ Bocconi University and IGIER
}

Massimiliano Marcellino

Bocconi University, IGIER and EUI

This Version: February 2000

\begin{abstract}
This paper addresses the issue of whether and by how much public capital can enhance economic performance. We apply different methodologies to Italian regional data for the period 1970-1994. The results are presented for Italy as a whole and for different macroregions, and for individual categories of public capital. For the Center and the South, the methodologies employed indicate a positive contribution of infrastructure investment to TFP growth, output, and cost reduction. However, the magnitude of the cost reducing effect does not seem large enough to outweigh the social user cost of public capital. Also, we get mixed results on which types of infrastructure are most effective. Overall, investment in transportation appears to be the most productive: railways in the North and roads in the Center and South are the categories that mostly contributed to TFP growth.
\end{abstract}

J.E.L. Classification: H54, O47, C50

\footnotetext{
${ }^{*}$ We are grateful to Tito Boeri, Francesco Daveri, Riccardo Faini, Francesco Giavazzi, Vittorio Grilli, Lucio Picci, Guido Tabellini and to seminar participants at the 1999 IGIER - Ministero del Tesoro Conference and at Harvard University for useful comments on an earlier version. We also thank Luca Opromolla for editorial assistance. Financial support by Bocconi University is gratefully acknowledged.
} 


\section{Introduction}

In the last half century, Italy has seen continuing efforts on behalf of its government to reduce regional disparities and spur economic growth via infrastructure investment. The policy of supposed targeting of southern regions in the allocation of public investment has been alternatively the source of political dissatisfaction and of confidence in the prospects of increased efficiency and growth. A symbol of the latter attitude is the recent volume "Cento idee per lo sviluppo" (Ministero del Tesoro, 1998), which has fueled a vivid debate among academics and policy-makers. The question is whether, and if so by how much, public investment is capable of increasing productivity, and also if there are regional differences in the extent to which infrastructure investment may be productive.

Recent studies have addressed these questions using time series data on Italian regions. Picci (1995a) estimates a production function which includes public capital among its inputs and finds that the latter has a positive and significant effect on production. In particular, he reports an elasticity of production to public capital of .43 and .35 with fixed and random effects, respectively. When performing robustness checks, however, he finds that this result is weakened. Acconcia and Del Monte (1999) estimate the contribution to real GDP growth of government spending in infrastructure and in consumption, and find that infrastructure investment is associated to higher growth, especially in the manufacturing sector. Furthermore, southern regions seem to be the ones for which this effect is stronger. Rossi and Toniolo (1993) follow a different methodology in estimating a cost function with a century long dataset for Italy (1880-1980). They focus on the relationships among production inputs, and find that public and private capital are substitutes in the short run but become complements in the long run for most of the sample period. Finally, Bonaglia (1997) applies the cost function methodology proposed by Morrison and Schwartz (1996) to Italian regional data, and finds that infrastructure investment leads to a significant cost reduction, especially in the North East and in the South. Under the hypothesis of increasing returns to fixed factors, he concludes that public investment should be directed to the South.

The interest in the productive effects of public capital is not an Italian prerogative. Not only there have been analogous studies for other European countries (e.g., De 
la Fuente and Vives (1995), who argue in favor of a positive role for infrastructure investment in reducing disparities among Spanish regions), but also the United States, which are not notorious for a policy of high state interventionism, have seen a growing interest in the returns to public infrastructure. Using state level data for the US, Hulten and Schwab (1991) estimate the effect of public capital accumulation on the growth rate of total factor productivity (TFP) and find a weak relationship among the two. Aschauer (1989) includes public capital as an input in the production function and estimates an elasticity of about .35. This estimate is consistent with that found by Munnel (1990) when using data for the US as a whole, but higher than the elasticity found with state level data (approximately .15). Even more in contrast with these results, Evans and Karras (1994) and Holtz-Eakin (1994) find that, once state fixed effects are included, the contribution of public capital to production is no longer significant. Finally, Morrison and Schwartz $(1994,1996)$ consider the effect of infrastructure investment on production costs, and find that public capital has a cost reducing effect, though limited in size and generally close to zero once the efficiency loss related to tax financing of public investment is taken into account. ${ }^{1}$

This paper is an attempt to provide a systematic and comprehensive assessment of the impact of public capital on economic performance. It uses the same dataset (regional data for Italy for the period 1970-1994) and applies all the different methodologies that have been used in the literature on the US. The detailed theoretical framework and links among the approaches can be found in La Ferrara and Marcellino (1999). Furthermore, we provide estimates separately for different macroregions, to allow for varying degrees of effectiveness across geographical areas, and for single categories of public capital, to investigate which components of infrastructure are more efficiency enhancing. All estimates include fixed and time effects to control for unobserved region specific effects and for spurious correlation.

Our findings show first of all marked differences in the sources of growth in different geographic areas. Overall, the relatively high growth rates of the North East and the Center are mostly attributable to higher than average total factor productivity growth. Both labor and private capital in fact grew little in those regions in the

\footnotetext{
${ }^{1}$ For a model in which the costs and benefits of public capital are embodied in an endogenous growth framework, see Barro (1990).
} 
sample period. The South, on the contrary, had relatively low TFP growth rates and managed to achieve an average growth rate of real value added around 2 percent per year thanks to significant private capital accumulation. Starting from these facts, we can expect to find interesting differences in the impact of public infrastructure on productivity in Northern, Central, and Southern regions.

The first methodology we apply relates TFP growth to the growth in the stock of public capital. According to this methodology, the share of TFP growth that can be attributed to public capital accumulation is approximately 0.47 for the whole of Italy. The effect seems to be larger and more significant for southern regions (0.61). The second approach estimates the contribution of public capital to output creation through a Cobb-Douglas production function. Again, we find a generally positive elasticity of output to public capital, quantitatively relevant for the Center (0.16) and the South (0.49). Finally, we assess whether and to what extent public capital leads to a reduction in the costs faced by manufacturing firms. We find that it does for the Center and the South, with an elasticity of total costs to public capital of 0.3 and 0.03, respectively. However, when the "social user cost" of public capital is taken into account, the benefits in terms of cost reduction are generally not high enough to outweigh the opportunity cost of public investment. This result, however, should be interpreted with caution, given that the available measures of "social user cost" of public capital are very imperfect and likely upward biased.

The rest of the paper is organized as follows. In section 2 we present descriptive statistics on the main variables of interest and discuss their regional patterns. In section 3, we present the growth accounting approach (the one related to TFP growth) and report the econometric results. In sections 4 and 5 we do the same, for the production function and the cost function approach, respectively. In section 6 we summarize the main conclusions of the study. Finally, in the Appendix we provide detailed variable definitions and data sources.

\section{Descriptive analysis}

In this section we present descriptive statistics on the main variables under analysis, namely, real value added for the industrial sector, labor, and private and public 
capital. All the data are at the regional level, on a yearly basis for the period 19701994. A finer disaggregation is not possible for a long enough time period, and more recent data on public capital are not available. A detailed definition of the variables and their sources can be found in the Appendix.

Figure 1 decomposes the average growth rate of real value added $(Q)$ into the components attributable to the growth of private capital $(K)$, labor $(L)$, and total factor productivity $(A)$. Results are presented for Italy and separately by macroregion, for North West, North East, Center, and South. Details on the composition of the macroregions can be found in the Appendix. Starting from the expression

$$
\dot{Q}=S^{K} \stackrel{\bullet}{K}+S^{L} \stackrel{\bullet}{L}+\dot{A},
$$

with $S^{L}$ and $S^{K}$ being the output shares of labor and capital, the bars of each histogram report, in the order, $\dot{Q}, S^{K} \stackrel{\bullet}{K}, S^{L} \stackrel{\bullet}{L}$, and $\dot{A} .^{2}$

\section{[Insert FIGURE 1 here]}

Over the sample period, the annual growth rate of real value added was on average $2 \%$. The worse performance was in the North West $(0.9 \%)$, the best one in the North East (2.9\%). The Center and the South grew at $2.5 \%$ and $1.9 \%$, respectively. Overall the good relative performance of North Eastern and Central regions seems to be mostly attributable to higher than average TFP growth. The North West had a respectable TFP growth rate, but did markedly worse in terms of labor (and partly capital) accumulation. But the most striking fact is that overall the South had higher labor and capital growth rates than the North East, yet grew roughly one percentage point less per year. A possible explanation for this pattern is the policy of incentives to private investment and hiring in the South. Some authors, e.g. Prosperetti and Varetto (1991), argue that this policy has led to 'overcapitalization' and, in general, to a relative inefficiency of southern firms compared to northern ones. Others, e.g., Del Monte and Giannola (1997), view the relatively high capital labor ratio in the south as a rational response by firms to the presence of higher costs of intermediate

\footnotetext{
${ }^{2}$ Expression (1) can be derived from a generic production function $Q=A F(L, K)$ assuming constant returns to scale, so that $S^{L}$ and $S^{K}$ sum to 1 , and $\dot{A}$ can be computed as a residual.
} 
$\operatorname{goods}^{3}$

The single most important factor responsible for the regional growth differentials appears to be TFP growth. It has been widely recognized in the literature that public investment in infrastructure is one of the main potential determinants of TFP. In what follows, we turn to investigate whether this holds for Italian regions. To start with, Figures 2 and 3 map, respectively, TFP and public capital $(K G)$ growth rates by region. High growth rates of $K G$ or TFP are represented by a darker shading. A pattern of high bivariate correlation between these two variables should result in a close matching between the "dark" regions across the two figures. This pattern holds only to a limited extent. Notable exceptions are Liguria, Emilia Romagna and Toscana in the North-Center where high TFP growth is associated with low public capital accumulation. The smallest regions, Val d'Aosta, Molise and Basilicata display the opposite pattern, i.e., high KG growth and low TFP growth. This situation is reflected in the low correlation coefficients reported in Table 1, first column. The remaining columns of Table 1 display the correlations between the growth rates of TFP and of different categories of public capital, to investigate whether any specific type of KG tends to be systematically associated with growth. Again, no clear-cut conclusions can be drawn.

\section{[Insert Figures 2-3 here] \\ [Insert TABLE 1 here]}

In Table 2 we further explore the decomposition of public capital into categories, reporting the growth rate and the percentage of total for each of them, see the Appendix for a description of the components of each category. As we can see from the first column, the average annual growth rate of public capital in Italy was $2.7 \%$ over the period 1970-94, about one percentage point lower than that of private capital. Of all the components of public capital, Communications, Education, and Marine are those that grew fastest $(6.0 \%, 6.3 \%$, and $10.8 \%$, respectively). However, their shares in total KG are quite low. In fact, the categories that account for the largest

\footnotetext{
${ }^{3}$ In Del Monte and Giannola's view the relative 'inefficiency' of southern firms is due to the fact that the latter are forced to integrate vertically, due to the higher costs of intermediate inputs, hence cannot take full advantage of specialization.
} 
fractions of KG are Roads (35.6\%), Water (17.6\%), Sanitation (14.2\%), and Land Reclaimation (11.9\%).

\section{[Insert TABLE 2 here]}

The regional disaggregation displayed in Table 2, yields interesting results. First of all, contrary to common beliefs, public capital has grown faster in the North than in the Center and the South $3.0 \%$ and $3.1 \%$ in the North West and North East compared to $2.3 \%$ in the Center and $2.5 \%$ in the South). The widely held notion that the South receives a disproportionate share of public spending compared to the Center and especially the North must be understood as related to transfer payments as opposed to public investment in capital goods. Public capital growth in fact was higher in the South than in the North only in the '70s.

Macroregions also differ in the composition of public capital: while in the NorthWest and Center the share of Roads is higher than average, in the North East this holds for Education and Water, and in the South for Land reclaimation, Sanitation, and Marine. On the other hand, Southern regions have markedly lower levels of Roads, Railways, and Water. The components that grew much faster in the North East compared to the national average are Land reclaimation and Sanitation; the growth rate of Communications, Water, and Marine was higher than average in the North West and that of Railways in the Center. The South had relatively high growth of Education and Roads.

A warning on these and all the forthcoming results is in order. Given that the stock of public capital is constructed using the permanent inventory method, this measure will be overestimated for regions where public spending is least efficient. The proper measure of $K G$ should be a physical index, but such a measure is not available on a time series basis. In fact, Bracalente and Di Palma (1982) built an index for the year 1977, Biehl et al. (1990) for 1970 and 1987, and only preliminary results are available for 1995 from Di Palma et al. (1998). Preliminary evidence by Picci (1995b) shows that southern regions are ranked systematically higher with the permanent inventory method than with physical index. Despite these discrepancies, we are forced to use the investment-based measure of $K G$ due to lack of data.

Moreover, before drawing any conclusions on the role of public capital in enhancing growth, or on the relative importance of its components, we need to take into account 
other possible determinants, and therefore we turn to multivariate analysis.

\section{Growth accounting}

The first formal method that we use to assess the contribution of public capital is related to a simple growth accounting procedure. Starting from the expression (1), we can compute TFP growth $(\dot{A})$ and estimate how much of its variation can be explained by the growth of $K G$. We therefore estimate the following regression:

$$
\dot{A}_{i t}=\alpha \dot{K}_{i t}+\beta \dot{K}_{i t}+\gamma_{i}+\varepsilon_{i t},
$$

where $i$ indexes regions, $t$ years, $\gamma_{i}$ is a region specific fixed effect, and $\varepsilon_{i t}$ is an i.i.d. error term. It can be shown that the coefficient on $\dot{K} G$ measures the elasticity of output with respect to public capital, while $\dot{K}_{i t}$ is included among the regressors to account for the possibility of non-constant returns to scale (see Hulten and Schwab, 1991).

\section{[Insert TABLE 3 here]}

In Table 3 we report estimates of equation (2) for Italy and the four macroregions. ${ }^{4}$ Overall, the growth of public capital has a positive and rather large impact on TFP growth (0.47), while the negative coefficient on private capital growth suggests the presence of decreasing returns to private inputs $(-0.14)$. When we disaggregate, we find that the impact of $\dot{K} G$ is positive everywhere but in the North-East, though it is only statistically significant for the South (possibly as a result of a lower standard error because of a larger sample size).

\section{[Insert TABLE $4 \mathrm{a}$ and $4 \mathrm{~b}$ here]}

In Table 4a we attempt to separate the impact of different categories of public capital. In the full sample (column 1) very little seems to be going on: no single category has a distinct impact on productivity aside from Water, which comes out

\footnotetext{
${ }^{4}$ The empirical results for the growth accounting and the production function approaches are obtained with Stata 5.0. For the cost function estimation we used TSP 4.1. The programs are available upon request.
} 
with a negative coefficient, and Roads and Other ${ }^{5}$ which have positive though not significant coefficients. When we estimate macro regions separately, some patterns of 'specialization' emerge, though most coefficients are not statistically significant. Roads appear to have a positive coefficient in the Center and the South but a very negative one for the North-East and North-West. The latter two, on the other hand, seem to benefit from public investment in railways. The other main category with a positive impact (except for the North-East) is Other. Water has a negative coefficient across all macroregions.

In Table 4b we aggregate the various categories of $K G$ into three main groups: AllWater, that includes water, sanitation and reclaimation; AllTransports, that includes roads, railways, and marine; AllOther, that includes, communications, education, and the residual category "other". The results do not improve but we will come back to this Table when discussing its counterpart for the production function method.

Finally, a potential objection to the above results is that our regressors may be endogenous. La Ferrara and Marcellino (2000) consider several possible instruments, including lags of $\dot{K} G$ and an average of $\dot{K} G$ for neighboring regions, but the Hausman test suggests that there are no problems of endogeneity.

\section{Production function}

The second approach we follow is to include public capital as a direct input into the production function, and estimate its contribution to output creation, on the lines of Aschauer (1989) and Holtz-Eakin (1994). Assuming a Cobb Douglas technology with constant returns to all inputs, we estimate the following equation

$$
q_{i t}-l_{i t}=\alpha\left(k_{i t}-l_{i t}\right)+\beta\left(k g_{i t}-l_{i t}\right)+\gamma_{i}+\delta_{t}+\varepsilon_{i t} .
$$

$Q$ and $L$ are, respectively, real value added and units of labor, all variables are in $\operatorname{logs}$ (lower-case letters), $\alpha$ and $\beta$ are the elasticities of $Q$ to $K$ and $K G, \gamma_{i}$ and $\delta_{t}$ are fixed and common time effects. The parameter of interest for our analysis is the elasticity of production to public capital, $\beta$.

\section{[Insert TABLES 5 and 6 here]}

\footnotetext{
${ }^{5}$ The category "Other" includes gas pipelines and infrastructure for tourism.
} 
Results for Italy and macroregions are reported in Table 5. The impact of KG is positive and significant for all macroregions, except the North-West, and is rather sizeable for the South (0.49). As for private capital, the estimated coefficient for Italy is 0.14 , although for the single macroregions we get mixed results. ${ }^{6}$ Overall, the qualitative pattern that emerges is consistent with what we found in the growth accounting, namely, KG seems to be relatively more productive in Central and Southern regions. We next disaggregate public capital into the three broad categories defined above: AllWater, AllTransport, AllOther. ${ }^{7}$ From Table 6, investment in transportation appears as the most productive component in all regions except the Center, where AllWater is the most prominent category. The pattern is more marked than in the growth accounting (see Table $4 \mathrm{~b}) .^{8}$

\section{Cost function}

The last approach we pursue is the estimation of a cost function, in order to assess whether public infrastructure generates cost savings for the industrial sector, adapting the methodology of Morrison and Schwartz $(1994,1996)$ to the Cobb-Douglas functional form to make results more directly comparable to the previous approaches.

To distinguish fixed and variable costs, we split $K$ into variable private capital, $K_{T}$ (e.g., transport), and quasi fixed private capital, $K_{B}$ and $K_{M}$ (buildings and machinery, respectively). If we denote by $G(\cdot)$ a Cobb-Douglas variable cost function, we can write total costs as

$$
C=G\left(P_{T}, W, K_{T}, K G, t, Q\right)+P_{M} K_{M}+P_{B} K_{B}
$$

where $P_{T}$ is the user cost of variable private capital, $W$ is the price of labor, $t$ is a linear trend, and $P_{M}$ and $P_{B}$ are the user costs of quasi-fixed private capital. Notice

\footnotetext{
${ }^{6}$ The negative coefficients for North-West and North-East are likely due to the anomalous decreasing pattern of the labor input in these areas.

${ }^{7}$ We do not use the finer disaggregation of public capital because of the fewer degrees of freedom (due to the presence of time dummies).

${ }^{8}$ Regarding the effect of transportation, different conclusions would be obtained under a model a' la Krugman-Venables, where infrastructure can adversely affect poor regions by lowering transport costs and inducing firms to locate in richer regions. Indeed, Faini (1983) argued that in the '50s a similar effect contributed to the deindustrialization of Southern Italy.
} 
that $K G$ does not appear as a direct cost because it is assumed to have a zero price for the firm. On the other hand, it enters $G(\cdot)$ because $K G$ can potentially lead to a more efficient use of other inputs, hence to a reduction of variable costs.

The system we estimate is formed by the variable cost function (in logs), the factor share equation for labor, and the optimality condition $\left(P_{Q}=M C\right)$, as follows ${ }^{9}$

$$
\begin{gathered}
g_{i t}-p_{t}^{T}=\beta_{q} q_{i t}+\delta_{g} k g_{i t}+\delta_{m} k m_{i t}+\delta_{b} k b_{i t}+\beta_{L}\left(w_{i t}-p_{t}^{T}\right)+\alpha_{i}+\gamma t+\varepsilon_{i t}, \\
S_{L i t}=\beta_{L}+\eta_{i t} \\
p_{i t}^{Q}=\delta_{g} k g_{i t}+\delta_{m} k m_{i t}+\delta_{b} k b_{i t}+\beta_{L} w_{i t}+\beta_{T} p_{t}^{T}+\alpha_{i}+\gamma t+u_{i t},
\end{gathered}
$$

where lower case letters indicate logs.

The estimated parameters are then used to calculate the shadow values of private and public capital, $z_{K M t}, z_{K B t}$, and $z_{K G t}$, defined as the opposite of the marginal change in variable cost due to a change in the respective input:

$$
z_{X t}=-\frac{\partial G_{t}}{\partial X_{t}} \quad X=K G, K_{M}, K_{B}
$$

$>$ From $z_{K G t}$ we calculate the elasticity of cost to public capital. Assuming a zero user cost for public capital, it follows

$$
S_{K G t}=-\frac{\partial \log C_{t}}{\partial \log K G_{t}}=z_{K G t} \frac{K G_{t}}{C_{t}} .
$$

In the terminology of Morrison and Schwartz $(1994,1996)$ this is the shadow share of public capital. Positive values imply that public capital is cost reducing.

The first row of Table 7 reports the average value of $S_{K G t}$ over the period 1970-94 for Italy and the macroregions. The pattern is overall consistent with what we found in the other two approaches, namely, public capital is cost reducing in the Center and South, but not in Northern regions.

The last exercise we perform is to compare the shadow value of each type of capital with a measure of its opportunity cost, say $c_{X t}$ for $X=K G, K_{M}, K_{B}$. We construct the following indexes

$$
E_{X t}=\left(c_{X t}-z_{X t}\right) X_{t} / C_{t}, \quad X=K G, K_{M}, K_{B}
$$

\footnotetext{
${ }^{9}$ As a reference, see Greene (1997), pp. 689-98 and Berndt (1991) ch. 9.
} 
A positive value of $E_{X t}$ signals overinvestment in $X$, and a negative value underinvestment.

$>$ From the second row of Table 7 , we would be led to conclude that the benefits from public investment have not been high enough to outweigh its opportunity cost even in the Center and South. Yet, a major caveat is in order. It is extremely difficult to obtain a reliable measure of the social cost of public capital, and we use as a proxy the deflator of public investment multiplied by $(r+\delta)$, where $r$ is the real interest rate and $\delta$ is the depreciation rate. What we obtain is higher than the user cost of private capital because the fiscal and financial benefits available to private firms are not deducted (see the Appendix for a detailed definition). It is possible therefore that we are overestimating the social user cost of public capital. ${ }^{10}$

The last two rows of Table 7 present analogous results for private capital in machinery and buildings. For the whole of Italy, only private capital in machinery has benefits that outweigh its costs, and this seems to be mostly attributable to NorthWestern regions. On the other hand, investment in buildings appears to be most convenient for the North-East.

\section{Conclusions}

This paper has addressed the issue of whether and by how much public capital can enhance economic performance. We have applied different methodologies to the same dataset, i.e., Italian regional data for the period 1970-1994. The results have been presented for Italy as a whole and for different macroregions, and for individual categories of public capital. For the Center and the South, the methodologies employed have all indicated a positive contribution of infrastructure investment to TFP growth, output, and cost reduction. However, from the cost function approach, the magnitude of the cost reducing effect does not seem large enough to outweigh the social user cost of public capital. Also, we have got mixed results on which types of infrastructure are most effective. Overall, investment in transportation appears to be the most productive: according to the growth accounting approach railways in the

\footnotetext{
${ }^{10}$ We do not report results for the various categories of public capital as in the previous approaches because we do not have enough degrees of freedom due to the high parametrization of the cost system.
} 
North and roads and airports in the Center and South are the categories that mostly contributed to TFP growth.

\section{References}

[1] Acconcia, A. and A. Del Monte (1999), "Regional Development and Public Spending. The Case of Italy", mimeo, Università degli Studi di Napoli Federico II.

[2] Aschauer D. (1989), "Is Public Expenditure Productive?", Journal of Monetary Economics, Vol. 23, No. 2, 177-200.

[3] Barro, R. (1990), "Government Spending in a Simple Model of Endogenous Growth", Journal of Political Economy, 98(5), 103-25.

[4] Berndt, E.R. (1991), The Practice of Econometrics, Addison-Wesley.

[5] Berndt, E.R. and D.O. Wood (1975), "Technology, Prices and the derived Demand for Energy", The Review of Economics and Statistics, Vol. 57, No.3, 259268.

[6] Biehl, D., B. Bracalente, M. Di Palma, C. Mazziotta (1990), "La Diffusione Territoriale delle Infrastrutture: un'Analisi per l'Europa e per l'Italia", in M. Di Palma (ed.), Le Infrastrutture a Rete. Dotazioni e Linee di Sviluppo, Centro Studi Confindustria.

[7] Bonaglia, F. (1997), "Capitale Pubblico e Crescita della Produttività Totale dei Fattori. Quale Evidenza dalle Regioni Italiane", unpublished.

[8] Bonaglia, F. and Picci L.(1999), "Lo stock di capitale nelle regioni italiane", unpublished.

[9] Bracalente, B. and M. Di Palma (1982), "Infrastrutture e Sviluppo Regionale in Italia: un'Analisi Multidimensionale", Note Economiche, 13-42.

[10] De la Fuente, A. and X. Vives (1995), "Infrastructure and Education as Instruments of Regional Policy: Evidence from Spain", Economic Policy, 13-51. 
[11] Di Palma, M., C. Mazziotta and G. Rosa (1998), "Infrastrutture e sviluppo. Primi risultati: indicatori quantitativi a confronto (1987-95)", I quaderni dell'area politiche territoriali e mezzogiorno, n. 4, Ecoter.

[12] Evans P., G. Karras (1994), "Are Government Activities Productive? Evidence from a Panel of US States", The Review of Economics and Statistics, 76, 1-11.

[13] Faini, R. (1983), "Cumulative Process of Deindustrialization in an Open Region: The Case of Southern Italy 1951-73", Journal of Development Economics.

[14] Greene, W.H. (1997), Econometric Analysis, Prentice Hall.

[15] Hall, R.E. and D.W. Jorgenson (1967), "Tax Policy and Investment Behaviour", American Economic Review, 57(3), 391-414.

[16] Holtz-Eakin D. (1994), "Public-sector Capital and the Productivity Puzzle", The Review of Economics and Statistics, Vol. 76, No. 1.

[17] Hulten C.R. and R. M. Schwab (1991), "Public Capital Formation and The Growth of Regional Manufacturing Industries", National Tax Journal, Vol. 44, No. 4, pp.121-134

[18] King, M A. (1972), "Corporate Taxation and Dividend Behaviour: A further Comment", The Review of Economic Studies, 39, 231-34.

[19] La Ferrara, E. and M. Marcellino, (1999), "TFP, Costs, and Infrastructure: An Equivocal Relationship", unpublished.

[20] Ministero del Tesoro, del Bilancio e della Programmazione Economica (1998), Cento Idee per lo Sviluppo, Catania.

[21] Morrison C., A. Schwartz (1994), "Distinguishing External from Internal Scale Effects: The Case of Public Infrastructure", The Journal of Productivity Analysis, Vol. 5, pp. 249-270.

[22] Morrison C., A. Schwartz (1996), "State Infrastructure and Productive Performance", The American Economic Review Vol. 86, No. 5, pp.1095-1112. 
[23] Munnell, A. (1990), "Why Has Productivity Growth Declined? Productivity and Public Investment", New England Economic Review, 3-22.

[24] Picci L.(1995a), "Productivity and Infrastructure in the Italian Regions", working paper, Dipartimento di Scienze Economiche, Università di Bologna.

[25] Picci, L. (1995b), "Il capitale mancante nel Mezzogiorno italiano", working paper, Dipartimento di Scienze Economiche, Università di Bologna.

[26] Prosperetti, L., F. Varetto (1991), I differenziali di produttività Nord-Sud nel settore manifatturiero, Il Mulino, Bologna.

[27] Rosa G., V. Siesto (1985), Il capitale fisso industriale. Stime settoriali e verifiche dirette, Bologna, Il Mulino.

[28] Rossi N., G. Toniolo (1993), "Un secolo di sviluppo economico", Rivista di Storia Economica, Bologna, Il Mulino.

[29] Schiantarelli, F. and Marotta, G. (1981), "Nota sulla Stima del Prezzo Effettivo dei Beni Capitali per il Settore della Trasformazione Industriale in Italia. 196076", in N. Rossi and R. Rovelli, Ricerche di Economia Applicata: Il Caso Italiano, Angeli. 


\section{Appendix}

Our analysis focuses on the regional industrial sector, that includes Industry, Energy and Constructions. The main sources that we use to construct the dataset are ISTAT, Contabilità nazionale. Tomo 3, Conti economici regionali (1997); SVIMEZ, I conti economici del Centro Nord e del Mezzogiorno nel ventennio 1970-89; V. Rosa and P. Siesto (1985); Fondazione Eni - Enrico Mattei, Banca dati regionale (1994), for the period 1960-1991, and CRENOS (1998), which basically updates the former to $1998 .^{11}$

The macroregions are defined in the following Table.

Macroregion Regions included

\begin{tabular}{ll}
\hline \hline North West & Piemonte, Val d'Aosta, Lombardia, Liguria \\
North East & Trentino Alto Adige, Veneto, Friuli Venezia Giulia,Emilia Romagna, \\
Center & Toscana, Umbria, Marche, Lazio \\
South & Abruzzo, Molise, Campania, Puglia, \\
& Basilicata, Calabria, Sicilia, Sardegna \\
\hline
\end{tabular}

A more detailed description of the variables in the analysis follows.

\section{A.1 Output}

Our output measure, $Q$, is regional value-added in constant 1990 billions of Lire. The price of output, $P_{Q}$, is given by the value-added deflator $(1990=1)$.

Due to the absence of data on intermediate and energy inputs, industrial (manufacturing) value-added is used instead of gross output. Data are obtained combining the series in ISTAT (1997) with those of Fondazione "E. Mattei" (1994) and CRENOS (1998).

\footnotetext{
${ }^{11}$ These two datasets combine information on different periods coming from various sources. For the period 1959-63: G. Tagliacarne, "Calcolo del reddito e del prodotto", supplement to "Moneta e Credito" (various years). For the period 1963-1970: Unioncamere (1974) "I Conti Economici Regionali 1963-71". For the period 1970-1984: ISTAT (1986), "Annuario di Contabilità Nazionale, Tomo II". Further details on data sources and methodology can be found in the original contribution, FEEM (1994).
} 


\section{A.2 Labor input}

The labor input $(L)$ is expressed as thousands of "total labor units" (unità di lavoro totali dell'industria), which include both dependent and autonomous workers. The price of labor $(W)$ is given by per capita annual earnings in millions of current liras (redditi da lavoro dipendente). This measure has the advantage of capturing the effective cost of labor, since it includes both gross remuneration of labor and social contributions (contributi sociali a carico del datore di lavoro, effettivi o figurativi). Since data on self-employed earnings are not available, we assumed them to be equal to the earnings of the dependent workers.

Labor market data come from: ISTAT, "Annuario di Contabilità Nazionale", "Le Regioni in cifre", "Annuario di Statistiche del lavoro", "Annuario Statistico Italiano", various years.

\section{A.3 Capital input}

We distinguish between private capital $(K)$ and public capital $(K G)$. The former is further disaggregated into "Machinery and Installations" $\left(K_{M}\right)$, "Transport Equipment" $\left(K_{T}\right)$ and "Industrial buildings" $\left(K_{B}\right)$.

Data on private capital stocks were built using the perpetual inventory method. (see, e.g., Bonaglia and Picci, 1999)). In order to build the capital stock for the period of interest (1970-1994), we need constant price fixed-investment series dating back at least $q$ years before 1970, where $q$ is the average economic life of the capital good considered.

ISTAT (1997) provides regional series on fixed investments for the 1980s, while data for previous years can be found in SVIMEZ and FEEM. To start with, we combined these different sources in order to obtain homogenous investment series at the regional level, covering the relevant period. These series do not distinguish among different kinds of capital goods. Therefore we had to make some assumptions on the relative weight of $K_{M}, K_{T}$ and $K_{B}$ in aggregate investment. In particular, we assumed that the national pattern of investment is reproduced at the regional level.

Data on the public capital stock, $K G$, (expressed in billions of 1990 liras) are taken from Bonaglia and Picci (1999). They are obtained cumulating public investment series by ISTAT, Indagine sulle Opere Pubbliche, again following the permanent 
inventory method. The categories of $K G$ are described in the Table.

\begin{tabular}{lll} 
Name & Istat Category & Description \\
\hline \hline Roads & 1. Roads & Highways and all kinds of roads \\
& 2. Airports & Landing strips, buildings \\
\hline Rail & 3. Railways & Railways, subways, cable-railway \\
\hline Mar & 4. Marine & Ports, lake and river navigation \\
\hline Water & 5. Water & River planning \\
& 6. Energy & Electric grid, power plants \\
\hline Com & 7. Communications & Telecommunications plants \\
\hline Educ & 8. Schools and social facilities & Schools, universities \\
& 9. Public buildings & Monuments, penitentiaries \\
& 10. Residential buildings & Subsidized residential buildings, \\
\hline & & reconstruction after calamity \\
\hline San & 11. Sanitation & Hospitals, water-filtering, water cysterns, sewers \\
\hline Land & 12. Land reclaimation & Land reclaimation and irrigation \\
& 13. Land transformation & Land improvement \\
\hline Other & 14. Other & Gas-pipelines, infrastructures for tourism \\
\hline \hline
\end{tabular}

Different measures of the capital stock have been used in productivity studies: gross capital stock, net capital stock, consumption of fixed capital, and gross fixed capital formation. We decided to use the net capital stock because it takes into account the reduced efficiency of older assets, instead of assuming that each vintage of goods has the same efficiency throughout its whole economic life. ${ }^{12}$

\section{A.4 The user cost of private capital}

The user cost of private capital $\left(c_{K t}\right)$ is defined as the cost of the services of a unit of capital in a time period. Hall and Jorgenson (1967) defined it as the opportunity cost

\footnotetext{
${ }^{12}$ Another relevant problem concerns the use of capital stocks to represent capital input, since both value added and labor are measures of flows. The appropriate measure of capital would be capital consumption. The use of the (more easily available) stock can be justified asssuming that capital services are proportional to the stock in place. The use of a gross stock would further exacerbate the problem.
} 
of using the capital input for a given tax rate on corporate income and a depreciation rule.

We build the user cost following the approach of King (1972), as it has been applied to the analysis of investment decision in Italy by Schiantarelli and Marotta (1981). Defining $p_{K t}$ the effective price of capital , $r_{t}$ the discount rate, and $\delta$ the depreciation rate,

$$
c_{K t}=p_{K t}\left(r_{t}+\delta\right) .
$$

The effective price $p_{K t}$ is the price paid for a unit of capital good, once fiscal and financial benefits are taken into account. It is obtained by adjusting the investment deflator, $p_{I t}$, for a comprehensive measure of those benefits: $p_{K t}=p_{I t}\left(1-U S_{t}\right)$. In particular, it is

$$
U S_{t}=\frac{1}{1+r_{t}\left(1-\tau_{t}\right)}\left[\frac{C C_{t}}{I_{t}}+\sum_{i=1}^{n} \frac{a_{i}+b_{i}}{\left(1+r_{t}\right)^{i}}\right]
$$

where $\tau_{t}$ is the tax rate on profits, $C C_{t}$ are government contributions to buy industrial capital given through Cassa del Mezzogiorno for the years in which it was operating, ${ }^{13}$ $I_{t}$ are investments in the industrial sector, $a_{i}$ and $b_{i}$ are normal and ahead depreciation coefficients. The discount rate, $r_{t}$, is set equal to the long term real interest rate (tasso di riferimento per il credito industriale degli Istituti di Credito Speciale; source: Banca d'Italia). The depreciation rate, $\delta$, depends on the average economic life assumed for each capital good ("Machinery and Installations": 15 years; "Transport Equipment": 10 years; "Industrial buildings": 35 years).

\section{A.5 The user cost of public capital}

Since public capital is not under the control of the firm and it is not possible to trace out a direct link between corporate taxation and the use of public infrastructure, there seems to be no explicit cost paid for this (public) good: its user cost, $c_{K G t}$, could therefore be set to zero. Nonetheless, we could be interested in assessing if more public investment is justified. This calls into question the notion of a social user cost of public capital. We build it using the deflator of public investment $\left(P_{I G t}\right.$,

\footnotetext{
${ }^{13}$ We use commitments rather than disbursements because the former are more relevant for investment decisions by firms.
} 
source CRENOS, 1998), but without adjusting it for taxation, i.e.,

$$
c_{K G t}=p_{I G t}\left(r_{t}+\delta\right) .
$$

The discount rate is the same used for private capital, while for the depreciation rate a 50 years economic life is assumed. 


\section{Tables}

Table 1: Correlations between TFP and public capital growth rates

\begin{tabular}{l|cccccccccc} 
& $K G$ & Land & Com & Educ & Water & San & Roads & Rail & Mar & Other \\
\hline ITALY & 0.071 & 0.015 & -0.014 & 0.037 & -0.017 & 0.000 & 0.029 & 0.055 & 0.044 & 0.030 \\
North-West & 0.028 & -0.037 & -0.069 & 0.135 & -0.081 & -0.164 & -0.024 & 0.160 & 0.230 & -0.023 \\
North-East & -0.070 & -0.039 & -0.028 & -0.109 & -0.181 & -0.110 & 0.030 & 0.059 & -0.018 & -0.081 \\
Center & 0.111 & 0.043 & 0.171 & -0.065 & 0.106 & 0.121 & 0.076 & 0.020 & 0.032 & 0.065 \\
South & 0.105 & 0.064 & 0.026 & 0.103 & -0.038 & 0.054 & 0.053 & -0.015 & -0.026 & 0.090 \\
\hline \hline
\end{tabular}

Notes: Land: Land Reclaimation; Com: Communications; Educ: Education;

San: Sanitation; Rail: Railways; Mar: Marine. 
Table 2: Summary statistics on public capital

\begin{tabular}{|c|c|c|c|c|c|c|c|c|c|c|}
\hline & $K G$ & Land & Com & $E d u c$ & Water & San & Roads & Rail & Mar & Other \\
\hline \multicolumn{11}{|l|}{ ITALY } \\
\hline Growth rate & 0.027 & 0.014 & 0.060 & 0.063 & 0.026 & 0.039 & 0.019 & 0.033 & 0.108 & 0.023 \\
\hline$\%$ of total & & 11.9 & 1.3 & 5.1 & 17.6 & 14.2 & 35.6 & 7.7 & 1.4 & 5.2 \\
\hline \multicolumn{11}{|l|}{ North-West } \\
\hline Growth rate & 0.03 & 0.019 & 0.080 & 0.058 & 0.042 & 0.047 & 0.016 & 0.029 & 0.181 & 0.032 \\
\hline$\%$ of total & & 2.1 & 1.9 & 7.1 & 20.6 & 12.7 & 41.4 & 8.8 & 0.6 & 4.8 \\
\hline \multicolumn{11}{|l|}{ North-East } \\
\hline Growth rate & 0.031 & 0.023 & 0.042 & 0.036 & 0.034 & 0.054 & 0.022 & 0.031 & 0.075 & 0.027 \\
\hline$\%$ of total & & 8.6 & 1.3 & 7.8 & 22.1 & 12 & 31.2 & 8.9 & 0.9 & 7.2 \\
\hline \multicolumn{11}{|l|}{ Center } \\
\hline Growth rate & 0.023 & 0.001 & 0.042 & 0.068 & 0.020 & 0.029 & 0.012 & 0.054 & 0.117 & 0.018 \\
\hline$\%$ of total & & 5.7 & 1.7 & 4.6 & 18.8 & 13 & 41 & 8.5 & 1.1 & 5.7 \\
\hline \multicolumn{11}{|l|}{ South } \\
\hline Growth rate & 0.025 & 0.014 & 0.067 & 0.077 & 0.018 & 0.033 & 0.023 & 0.026 & 0.090 & 0.018 \\
\hline$\%$ of total & & 21.6 & 0.8 & 3.1 & 13.2 & 16.6 & 32.2 & 6.1 & 2.2 & 4.1 \\
\hline
\end{tabular}

Notes: Land: Land Reclaimation; Com: Communications; Educ: Education;

San: Sanitation;Rail: Railways; Mar: Marine 
Table 3: Growth accounting

\begin{tabular}{l|ccccc} 
& Italy & $\mathrm{NW}$ & $\mathrm{NE}$ & $\mathrm{CEN}$ & $\mathrm{S}$ \\
\hline KG_g & $.471^{* *}$ & .449 & -.144 & .398 & $.616^{* *}$ \\
& $(.188)$ & $(.448)$ & $(.463)$ & $(.338)$ & $(.313)$ \\
K_g & $-.138^{* *}$ & -.317 & .276 & -.022 & $-.178^{* *}$ \\
& $(.061)$ & $(.262)$ & $(.227)$ & $(.141)$ & $(.08)$ \\
Const & .006 & .009 & .017 & .009 & -.001 \\
& $(.006)$ & $(.017)$ & $(.016)$ & $(.009)$ & $(.008)$ \\
$\mathrm{R}^{2}$ adj & .017 & .018 & .014 & .013 & .037 \\
$\mathrm{~N}^{o}$ obs & 480 & 96 & 96 & 96 & 192 \\
\hline \hline
\end{tabular}

Notes: Dependent variable is TFP growth.

Heteroskedasticity consistent standard errors in parentheses.

$*$ and ${ }^{* *}$ denote significance at $10 \%$ and $5 \%$, respectively. 
Table 4A: Growth accounting - Categories of public capital

\begin{tabular}{|c|c|c|c|c|c|}
\hline & Italy & North-West & North-East & Center & South \\
\hline \multirow[t]{2}{*}{ Land_g } & -.004 & -.167 & .327 & -.485 & .250 \\
\hline & $(.126)$ & $(.237)$ & $(.287)$ & $(.371)$ & $(.254)$ \\
\hline \multirow[t]{2}{*}{ Water_g } & -.328 & -.528 & -.416 & -.273 & -.300 \\
\hline & $(.206)$ & $(.384)$ & $(.722)$ & $(.511)$ & $(.355)$ \\
\hline \multirow[t]{2}{*}{ San_g } & -.005 & .130 & .112 & .155 & -.040 \\
\hline & $(.100)$ & $(.331)$ & $(.217)$ & $(.255)$ & $(.193)$ \\
\hline \multirow[t]{2}{*}{ Roads_g } & .162 & $-1.96^{* *}$ & $-.945^{* *}$ & .233 & .296 \\
\hline & $(.146)$ & $(.667)$ & $(.474)$ & $(.324)$ & $(.210)$ \\
\hline \multirow[t]{2}{*}{ Rail_g } & .020 & .395 & .337 & -.056 & -.086 \\
\hline & $(.084)$ & $(.406)$ & $(.233)$ & $(.117)$ & $(.158)$ \\
\hline \multirow[t]{2}{*}{ Mar_g } & .002 & $.036^{* *}$ & .056 & -.025 & -.002 \\
\hline & $(.009)$ & $(.017)$ & $(.087)$ & $(.023)$ & $(.018)$ \\
\hline \multirow[t]{2}{*}{ Com_g } & .026 & -.045 & -.002 & .095 & .037 \\
\hline & $(.034)$ & $(.077)$ & $(.144)$ & $(.081)$ & $(.051)$ \\
\hline \multirow[t]{2}{*}{ Edu_g } & .025 & -.160 & -.180 & -.028 & .080 \\
\hline & $(.039)$ & $(.210)$ & $(.213)$ & $(.07)$ & $(.062)$ \\
\hline \multirow[t]{2}{*}{ Other_g } & .185 & .544 & -.306 & .579 & $.443^{*}$ \\
\hline & $(.137)$ & $(.656)$ & $(.568)$ & $(.381)$ & $(.237)$ \\
\hline \multirow[t]{2}{*}{$K_{\text {_g }}$} & -.099 & .420 & .060 & .079 & -.135 \\
\hline & $(.070)$ & $(.459)$ & $(.308)$ & $(.203)$ & $(.090)$ \\
\hline \multirow[t]{2}{*}{ Const } & $.016^{* *}$ & $.045^{* *}$ & $.044^{* *}$ & .009 & -.006 \\
\hline & $(.008)$ & $(.025)$ & $(.021)$ & $(.014)$ & $(.013)$ \\
\hline $\mathrm{R}^{2}$ & .007 & .198 & .216 & .054 & .054 \\
\hline $\mathrm{N}^{o}$ obs & 419 & 71 & 48 & 109 & 191 \\
\hline
\end{tabular}

Notes: Dependent variable is TFP growth.

Heteroskedasticity consistent standard errors in parentheses.

$*$ and ${ }^{* *}$ denote significance at $10 \%$ and $5 \%$, respectively. 
Table 4B: Growth accounting - Categories of public capital

\begin{tabular}{l|ccccc} 
& Italy & North-West & North-East & Center & South \\
\hline Water_g & -.002 & -.115 & -.085 & .007 & .122 \\
& $(.059)$ & $(.136)$ & $(.095)$ & $(.170)$ & $(.101)$ \\
Trans_g & .007 & $.032^{*}$ & .001 & .004 & -.004 \\
& $(.008)$ & $(.017)$ & $(.069)$ & $(.009)$ & $(.018)$ \\
Other_g & .021 & -.019 & -.032 & -.003 & .046 \\
& $(.023)$ & $(.073)$ & $(.109)$ & $(.039)$ & $(.034)$ \\
K_g & -.077 & .163 & -.034 & .166 & -.114 \\
& $(.063)$ & $(.375)$ & $(.282)$ & $(.161)$ & $(.082)$ \\
Const & $.013^{* *}$ & .023 & $.037^{* *}$ & .012 & -.003 \\
& $(.006)$ & $(.017)$ & $(.016)$ & $(.010)$ & $(.011)$ \\
\hline $\mathrm{R}^{2}$ & .009 & .064 & .027 & .010 & .029 \\
$\mathrm{~N}^{o}$ obs & 419 & 71 & 48 & 109 & 191 \\
\hline \hline
\end{tabular}

Notes: Dependent variable is TFP growth.

Heteroskedasticity consistent standard errors in parentheses.

$*$ and ${ }^{* *}$ denote significance at $10 \%$ and $5 \%$, respectively. 
Table 5: Production function

\begin{tabular}{l|ccccc} 
& Italy & North-West & North-East & Center & South \\
\hline KG_L & .005 & .012 & $.114^{*}$ & $.163^{* *}$ & $.495^{* *}$ \\
& $(.029)$ & $(.100)$ & $(.063)$ & $(.077)$ & $(.075)$ \\
K_L & $.140^{* *}$ & $-.350^{* *}$ & $-.374^{* *}$ & $.409^{* *}$ & $.223^{* *}$ \\
& $(.021)$ & $(.148)$ & $(.101)$ & $(.035)$ & $(.024)$ \\
Const & $3.508^{* *}$ & $2.796^{* *}$ & $2.186^{* *}$ & $-1.098^{* *}$ & .121 \\
& $(.180)$ & $(.488)$ & $(.254)$ & $(.325)$ & $(.487)$ \\
\hline $\mathrm{R}^{2}$ adj & .974 & .985 & .996 & .996 & .929 \\
$\mathrm{~N}^{o}$ obs & 500 & 100 & 100 & 100 & 200 \\
\hline \hline
\end{tabular}

Dependent variable is (log of) value added per worker in industry.

$*$ and $* *$ denote significance at $10 \%$ and $5 \%$, respectively.

Heteroskedasticity consistent standard errors in parentheses. 
Table 6: Production function - Categories of public capital

\begin{tabular}{l|ccccc} 
& ITALY & North-West & North-East & Center & South \\
\hline Water_L & $-.100^{* *}$ & .037 & $-.327^{* *}$ & $.402^{* *}$ & .001 \\
& $(.027)$ & $(.101)$ & $(.044)$ & $(.079)$ & $(.098)$ \\
Trans_L & $.305^{* *}$ & $1.001^{* *}$ & $.133^{* *}$ & $-.390^{* *}$ & $.509^{* *}$ \\
& $(.043)$ & $(.104)$ & $(.065)$ & $(.116)$ & $(.096)$ \\
Other_L & $-.102^{* *}$ & $-.270^{* *}$ & .147 & .009 & .043 \\
& $(.022)$ & $(.065)$ & $(.157)$ & $(.027)$ & $(.083)$ \\
K_L & $.146^{* *}$ & $-.232^{* *}$ & .119 & $.452^{* *}$ & $.203^{* *}$ \\
& $(.019)$ & $(.092)$ & $(.102)$ & $(.037)$ & $(.027)$ \\
Const & $2.962^{* *}$ & -.654 & $.994^{* *}$ & $-.549^{*}$ & $-1.929^{* *}$ \\
& $(.166)$ & $(.529)$ & $(.228)$ & $(.282)$ & $(.366)$ \\
\hline $\mathrm{R}^{2}$ & .954 & .604 & .988 & .99 & .915 \\
$\mathrm{~N}^{o}$ obs & 500 & 100 & 75 & 125 & 200 \\
\hline \hline
\end{tabular}

Dependent variable is (log of) value added per worker in industry.

$*$ and ${ }^{* *}$ denote significance at $10 \%$ and $5 \%$, respectively.

Heteroskedasticity consistent standard errors in parentheses.

Table 7: Cost Function

\begin{tabular}{l|ccccc} 
& Italy & North-West & North-East & Centre & South \\
\hline$S_{K G}$ & -.029 & -.171 & -.086 & .202 & .016 \\
$E_{K G}$ & .275 & .491 & .3 & .092 & .371 \\
$E_{K M}$ & -.022 & -.09 & .177 & .041 & .088 \\
$E_{K B}$ & .198 & .223 & -.027 & .128 & .149 \\
\hline$N^{o}$ obs & 500 & 100 & 100 & 100 & 200 \\
\hline \hline
\end{tabular}

$S_{X}$ is the shadow share of $X$.

$E_{X}$ is $\left(U_{X}-Z_{X}\right) X / C$, where $U_{X}$ is the user cost of $X$ and $C$ are total costs.

The reported values are averages over the sample 1970-94. 
Figures

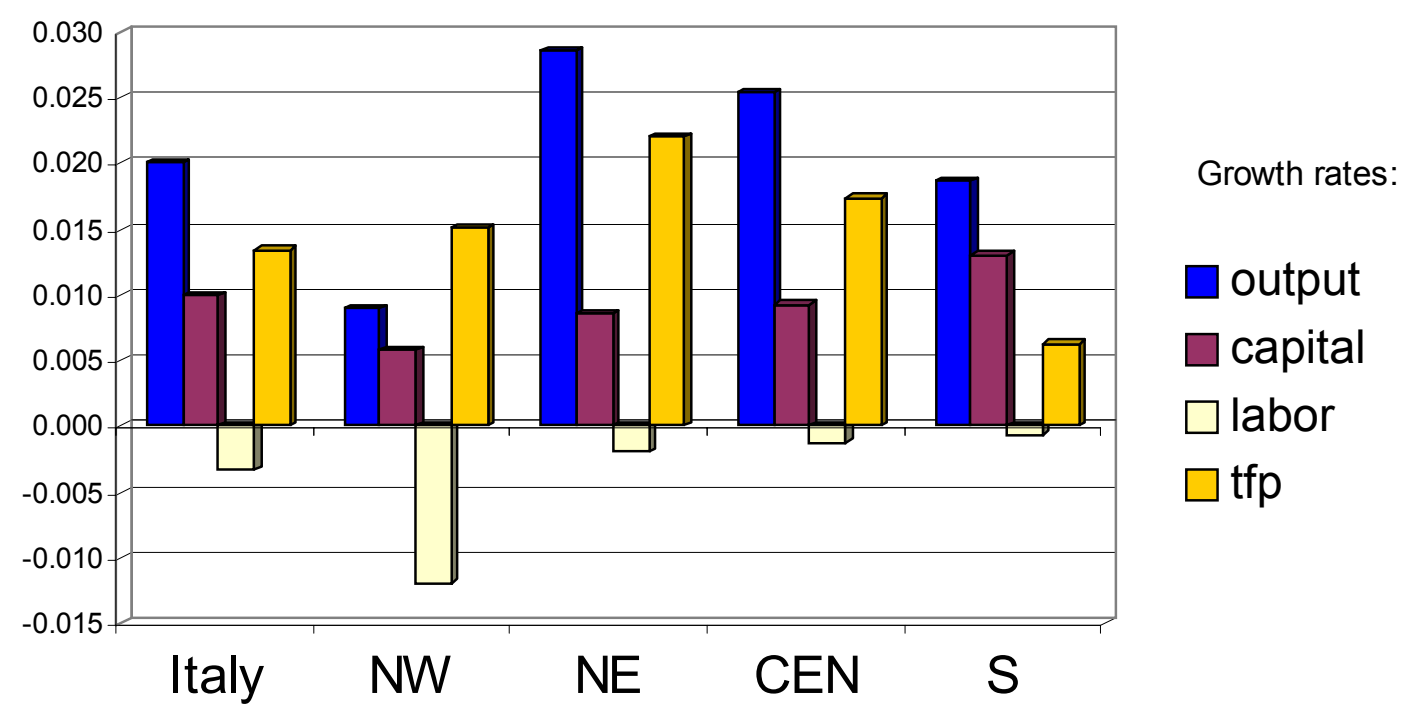

Figure 1: Growth Decomposition 


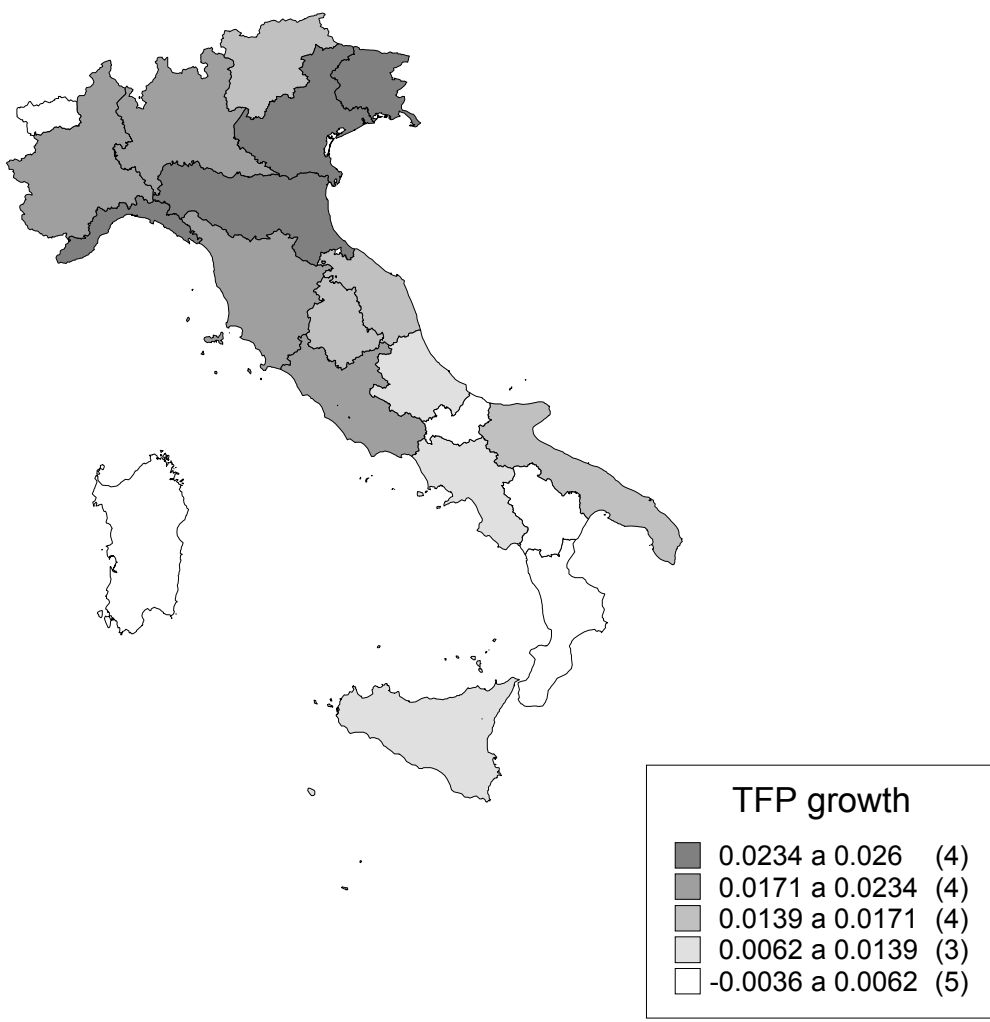

Figure 2: TFP growth 


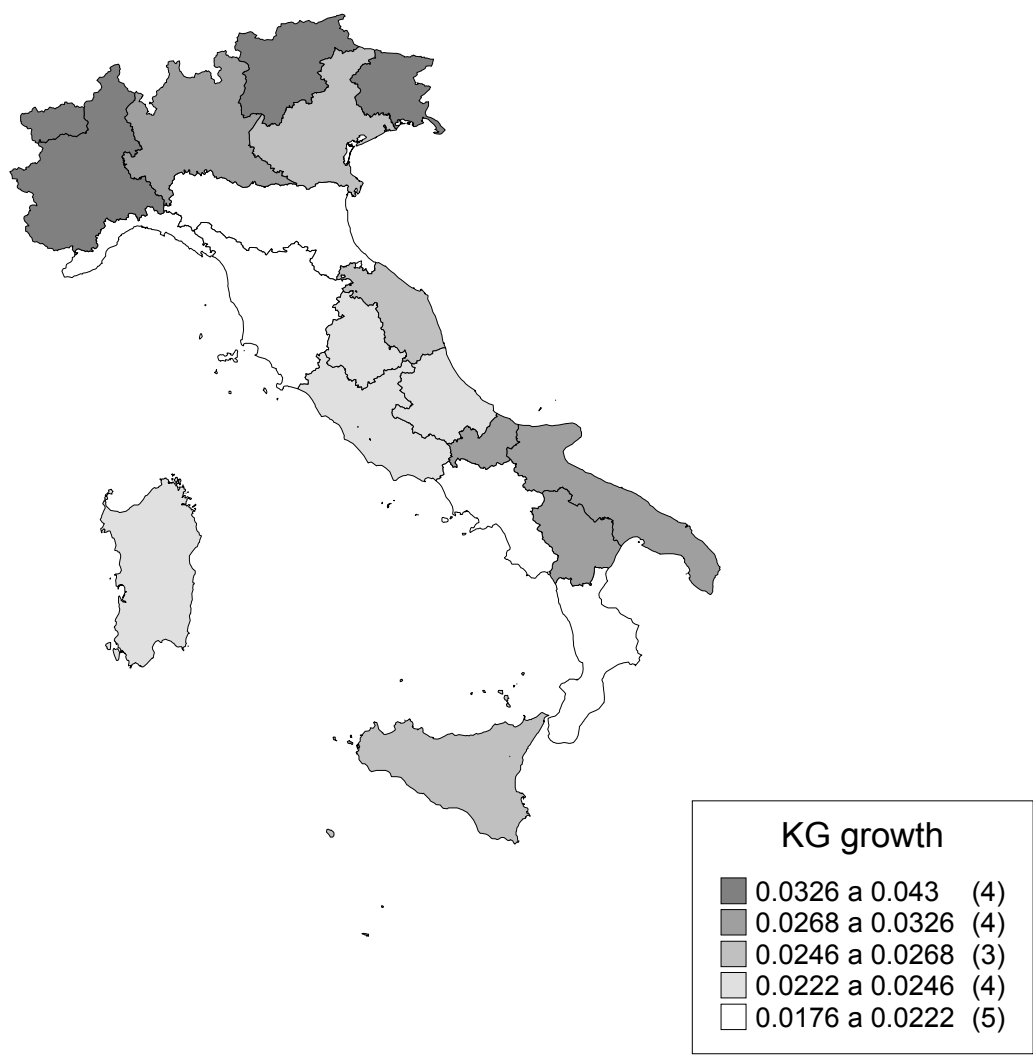

Figure 3: Growth of public capital 